\title{
PENGARUH PEMBELAJARAN FLIPPED CLASSROOM TERHADAP KEMANDIRIAN BELAJAR SISWA DITINJAU DARI GAYA KOGNITIF SISWA
}

\author{
Ela Priastuti Mirlanda ${ }^{1}$, Hepsi Nindiasari ${ }^{2}$, Syamsuri $^{3}$ \\ 1,2,3 Universitas Sultan Ageng Tirtayasa \\ ${ }^{1}$ ela.priastuti@yahoo.co.id \\ 2 hepsinindiasari@untirta.ac.id \\ ${ }^{3}$ syamsuri@untirta.ac.id
}

\begin{abstract}
ABSTRAK
Kemandirian belajar adalah kesiapan individu untuk belajar dengan inisiatif sendiri, dengan atau tanpa bantuan pihak lain dalam hal penentuan tujuan, metode dan evaluasi hasil belajar. Salah satu model pembelajaran yang dapat digunakan dalam upaya meningkatkan kemandirian belajar siswa adalah flipped classroom. Disamping itu, dalam penerapan pembelajaran ini perlu diperhatikan gaya kognitif siswa, yaitu cara khas siswa dalam memperoleh, menyusun dan menggunakan informasi untuk menghadapi dan menyelesaikan permasalahan. Salah satu kategori gaya kognitif siswa adalah gaya kognitif siswa adalah field dependent dan field independent. Penelitian ini menguji pengaruh model pembelajaran flipped classroom terhadap kemandirian belajar siswa ditinjau berdasarkan gaya kognitif siswa tersebut. Pada penelitian ini kelas eksperimen menggunakan model pembelajaran flipped classroom dan kelas kontrol menggunakan model pembelajaran saintifik. Jenis penelitian ini merupakan penelitian kuasi eksperimen dengan teknik pengambilan sampel cluster random sampling. Hasil penelitian menunjukkan bahwa : 1) peningkatan kemampuan kemandirian belajar siswa pada kelas flipped classroom lebih tinggi daripada kelas saintifik, 2) peningkatan kemampuan kemandirian belajar siswa field independent pada kelas flipped classroom lebih tinggi daripada kelas kontrol, dan 3) peningkatan kemampuan kemandirian belajar siswa field dependent pada kelas flipped classroom lebih tinggi daripada kelas kontrol.
\end{abstract}

Kata Kunci : flipped classroom, kemandirian belajar siswa, gaya kognitif siswa, field dependent, field independent

\begin{abstract}
Self regulated learning is the readiness of individuals who learn on their own initiative, with or without the help of others in terms of determining learning goals, learning methods and evaluating learning outcomes. A model can be used in an effort to improve student's self regulated learning is flipped classroom. Cognitive style is a characteristic or typical way of students in acquiring, compiling and using information to deal with and solve problems. Which categories of cognitive style is the field dependent and field independent. This study examines the effect of flipped classroom models on student's self regulated learning based on students' cognitive styles. In this study the experimental class used flipped classroom learning models and control class using scientific learning models. This type of research is quasi-experimental research with cluster random sampling. The results of this research are: 1) the increase of student's self regulated learning which have flipped classroom model was higher than the scientific class and 2) the increase of student's self regulated learning of field independent students which have flipped classroom model was higher than the control class. Likewise, the increase of student's self regulated learning of field dependent students which have flipped classroom model was higher than the control class.
\end{abstract}


Keywords: flipped classroom, self regulated learning, cognitive style, field dependent, field independent

\section{PENDAHULUAN}

Kurikulum 2013 menekankan pada pembelajaran yang mendorong peningkatan kompetensi, yaitu : 1) menanya (questioning); 2) memecahkan masalah (problem solving); 3) pembelajaran berbasis siswa (student center); 4) kerjasama (collaborative); dan 5) penalaran (reasoning). Kelima hal tersebut memastikan siswa menjadi subjek dalam membangun pengetahuan baru maupun menggali pengetahuan yang telah dimiliki menjadi semakin mendalam dan bermakna baik secara mandiri maupun dengan bekerja sama.

Dalam permendikbud nomor 24 tahun 2016 dirumuskan kompetensi inti untuk mata pelajaran matematika jenjang SMA pada aspek keterampilan adalah mengolah, menalar dan menyaji dalam ranah kongkret dan ranah abstrak terkait dengan pengembangan dari yang dipelajarinya di sekolah secara mandiri dan mampu menggunakan metoda sesuai kaidah keilmuan. Hal ini berarti dalam kegiatan belajar siswa dituntut secara mandiri untuk dapat membangun pengetahuan baik pada ranah konkret maupun ranah abstrak. Kemandirian belajar merupakan hal yang mempengaruhi pembelajaran terkait dengan berbagai proses seperti penetapan tujuan belajar, metakognisi, dan penilaian diri (Loyens et al., 2008). Namun kemandirian belajar bukan merupakan keterampilan mental atau keterampilan akademik seperti intelegensi atau kecakapan membaca. Kemandirian belajar lebih mengacu kepada proses mengubah kemampuan mental menjadi kemampuan akademik secara mandiri. Komponen yang terlibat dalam proses multidimensi ini adalah kognisi, emosi, perilaku dan lingkungan (Yamada et al., 2017). Dengan demikian kemandirian siswa memiliki pengaruh besar terhadap penguasaan keterampilan matematis mereka.

Hasil belajar matematika siswa dipengaruhi oleh berbagai faktor, diantaranya faktor guru, metode pembelajaran dan keaktifan siswa. Hal ini sejalan dengan hasil wawancara studi pendahuluan Nindiasari (2013) di salah satu SMA negeri yang menyebutkan bahwa karakter kemandirian belajar siswa masih belum nampak. Hal tersebut tercermin dari penyelesaian tugas siswa yang belum dikerjakan dengan baik. Siswa masih terpaku pada materi dan soal latihan yang diberikan oleh guru atau terdapat dalam buku paket. Pembelajaran saintifik yang digulirkan pemerintah untuk menjadi acuan dalam proses pembelajaran, pada pelaksanaannya masih kurang optimal. Guru masih kesulitan mengarahkan siswa untuk menemukan konsep yang diinginkan sehingga kadangkala menghabiskan waktu. Hal tersebut menyebabkan kemampuan kemandirian belajar siswa 
tidak berkembang secara optimal. Hal ini menunjukkan bahwa kesempatan siswa untuk membangun pengetahuan matematikanya masih belum optimal.

Kemandirian belajar merupakan salah satu faktor yang penting dalam menentukan keberhasilan siswa dalam belajar. Dengan berusaha sendiri atau mandiri, siswa akan memperoleh pengalaman yang konkrit, memberikan makna dan kepuasan tersendiri bagi siswa. Proses perancangan dan pemantauan diri yang seksama terhadap proses kognitif dan afektif dalam menyelesaikan suatu tugas akademik disebut dengan kemandirian belajar (Sumarmo, 2006). Kemandirian belajar merupakan kesiapan dari individu yang mau dan mampu untuk belajar dengan inisiatif sendiri, dengan atau tanpa bantuan pihak lain dalam hal penentuan tujuan belajar, metoda belajar dan evaluasi hasil belajar. Berkaitan dengan hal tersebut, karakteristik individu yang memiliki kesiapan belajar mandiri menurut Nindiasari (2013) adalah : 1) inisiatif belajar; 2) mendiagnosa kebutuhan belajar; 3) menetapkan tujuan/target belajar; 4) memonitor, mengatur, dan mengontrol belajar; 5) memandang kesulitan sebagai tantangan; 6) memanfaatkan dan mencari sumber yang relevan; 7) memilih, menerapkan strategi belajar; 8) mengevaluasi proses dan hasil belajar dan ; 9) self efficacy/konsep diri/ kemampuan diri. Kemandirian belajar melibatkan individu secara biologis, kontekstual dan lingkungannya. Pada akhirnya kemampuan kemandirian belajar muncul sebagai perantara antara keinginan dan pencapaian tujuan (Loyens dkk, 2008).

Penelitian tentang kemandirian belajar dengan scaffold pada pembelajaran berbasis komputer menyatakan bahwa scaffold berperan penting dalam keseluruhan pembelajaran self-regulated, walaupun hanya mengukur prestasi akademik (Zheng, 2016). Pintrich (Li, Xie, Li, \& Li, 2015) menyatakan bahwa kemandirian belajar terkait dengan motivasi, kognisi dan pengendalian diri karena diarahkan menuju pencapaian tujuan pembelajaran. Siswa yang memiliki kemampuan kemandirian belajar adalah mereka yang dapat menyiapkan rencana pembelajaran, menyesuaikannya dan menerapkan pengendalian diri dan evaluasi diri.

Pentingnya keaktifan siswa dalam upaya meningkatkan kemandirian belajar siswa, menjadikan guru harus mampu memberikan kesempatan kepada siswa melalui pembelajaran yang tepat . Cara yang dapat dilakukan adalah dengan menciptakan suasana belajar yang nyaman sehingga menimbulkan ketertarikan siswa untuk berlatih kemampuan tersebut dan menjadikan mereka mandiri dalam menyelesaikan permasalahan matematis, sehingga pembelajaran matematika dapat berjalan sesuai dengan yang diharapkan. Dari hasil penelitian Lo \& Hew (2017), Lee (2018) serta Yamada et al. (2017) menunjukkan bahwa kemampuan kemandirian belajar dapat ditingkatkan secara signifikan dengan model pembelajaran yang tepat. Salah satu metode yang dapat digunakan dalam upaya tersebut 
adalah model pembelajaran flipped classroom yang telah memberikan dampak positif peningkatan kemandirian siswa. Model pembelajaran flipped classroom yaitu pembelajaran kelas terbalik, yang biasanya dilakukan di kelas sekarang dilakukan di rumah, yang biasanya dilakukan sebagai pekerjaan rumah sekarang diselesaikan di kelas. Dalam penelitiannya Roehl et al (2013) dan Tucker (2012) menyatakan bahwa flipped classroom adalah sebuah pembelajaran di mana siswa memanfaatkan waktu di kelas untuk bekerja menyelesaikan masalah, pengembangan konsep dan terlibat dalam pembelajaran kolaboratif. Guru dapat mengefektifkan waktu untuk berinteraksi dengan siswa secara pribadi, membantunya menyelesaikan kesulitan dalam memahami konsep serta mengakomodasi setiap gagasan siswa.

Hal lain yang berpengaruh terhadap kemandirian belajar yaitu faktor intrinsik siswa diantaranya gaya kognitif siswa. Gaya kognitif adalah karakteristik atau cara khas siswa dalam memperoleh, menyusun dan menggunakan informasi untuk menghadapi dan menyelesaikan permasalahan. Salah satu kategori gaya kognitif siswa adalah gaya kognitif field dependent (FD) dan field independent (FI). Witkin, et al (1977) membagi gaya kognitif menjadi dua jenis yaitu field dependent dan field independent. Perbedaan mendasar dari kedua gaya kognitif tersebut yaitu dalam hal bagaimana melihat suatu permasalahan (Onyekuru, 2015). Individu dengan gaya kognitif field independent merupakan pribadi yang kompetitif, analitis, individualistis, berorientasi pada tugas, mampu memotivasi diri, mampu menguji hipotesis, sedangkan individu dengan gaya kognitif field dependent berorientasi kelompok, global, sensitif pada interaksi sosial dan kritik, termotivasi secara eksternal serta pasif dalam belajar lebih suka menerima informasi dari orang lain. Dalam aspek sosial, individu dengan gaya kognitif field dependent cenderung lebih mudah bergaul dan berinteraksi dengan lingkungan di sekitarnya, sementara individu dengan gaya kognitif field independent cenderung tidak mau terlibat dalam hubungan interpersonal.

Penjelasan tentang karakteristik siswa dengan gaya kognitif juga dipaparkan oleh Khoiriyah (2013) dalam penelitiannya. Siswa yang memiliki gaya kognitif FD cenderung membutuhkan instruksi yang jelas dalam merespon suatu masalah namun mereka memiliki ingatan yang baik tentang informasi sosial dan materi dengan muatan sosial. Sementara orang FI memiliki kemampuan lebih baik dalam menganalisis pola menjadi bagian-bagian yang lebih rinci, mampu mengorganisasi informasi kompleks dan tidak terstruktur untuk memecahkan masalah. Hal ini menyebabkan siswa FD cenderung memerlukan bantuan dan penguatan dari luar untuk mencapai tujuan, sedangkan siswa FI mampu memotivasi diri sendiri dalam mencapai tujuan. 
Berdasarkan hasil penelitian tersebut, maka penulis tertarik untuk melakukan penelitian dengan menerapkan metode flipped classroom sebagai stimulus untuk dapat meningkatkan kemampuan kemandirian belajar dalam pembelajaran mata pelajaran matematika ditinjau dari gaya kognitif siswa field dependent dan field independent. Tujuan dari penelitian ini adalah 1) mengetahui peningkatan kemampuan kemandirian belajar siswa yang memperoleh pembelajaran flipped classroom dan pembelajaran saintifik dan 2) mengetahui perbedaan peningkatan kemampuan kemandirian belajar antara siswa yang memperoleh pembelajaran flipped classroom dan saintifik berdasarkan gaya kognitif field independent dan field dependent.

\section{METODE PENELITIAN}

Penelitian ini menguji sebuah perlakuan, yaitu kemandirian belajar siswa melalui pembelajaran flipped classroom. Penelitian ini merupakan penelitian kuasi eksperimen, karena pada saat penelitian digunakan kelas-kelas yang telah tersedia karena tidak mungkin mengelompokan siswa secara acak. Jika dilakukan pengacakan kelas, maka efektivitas kegiatan pembelajaran di sekolah akan terganggu.

Agar diperoleh gambaran dari perlakuan maka dipilihlah kelompok pembanding, sehingga penelitian dilakukan pada siswa dari dua kelas yang memiliki kemampuan setara dengan model pembelajaran yang berbeda. Kelompok pertama diberikan pembelajaran dengan menggunakan model flipped classroom (kelompok eksperimen), sedangkan kelompok kedua memperoleh pembelajaran dengan pembelajaran saintifik (kelompok kontrol). Desain penelitian menggunakan desain kelompok Nonequivalent Control Group Design (Sugiyono, 2009). Syarat memilih desain ini yaitu kedua kelas harus homogen atau setara kemampuan awalnya. Hal ini didasarkan pada hasil observasi dan wawancara awal yang dilakukan oleh peneliti terhadap guru matematika yang mengajar pada saat itu dan wakil kepala sekolah bidang kurikulum yang menyatakan bahwa kedua kelas homogen dalam kemampuan kognitifnya.

Penelitian ini dilakukan di kelas X di SMAN 1 Rangkasbitung Kabupaten Lebak tahun pelajaran 2018/2019. Seluruh siswa kelas X di sekolah tersebut ditetapkan sebagai populasi. Teknik sampling yang digunakan pada penelitian ini adalah cluster random sampling (Sugiyono, 2009). Teknik ini merupakan salah satu jenis dari probability sampling, yaitu teknik pengambilan sampel yang memberikan peluang yang sama bagi setiap unsur, dalam hal ini kelas, untuk dipilih menjadi anggota sampel. Dari enam kelas X di sekolah tersebut, dipilih dua kelas untuk menjadi sampel penelitian. 
Tahapan kegiatan yang dilakukan dalam penelitian ini terdapat pada Gambar 1.

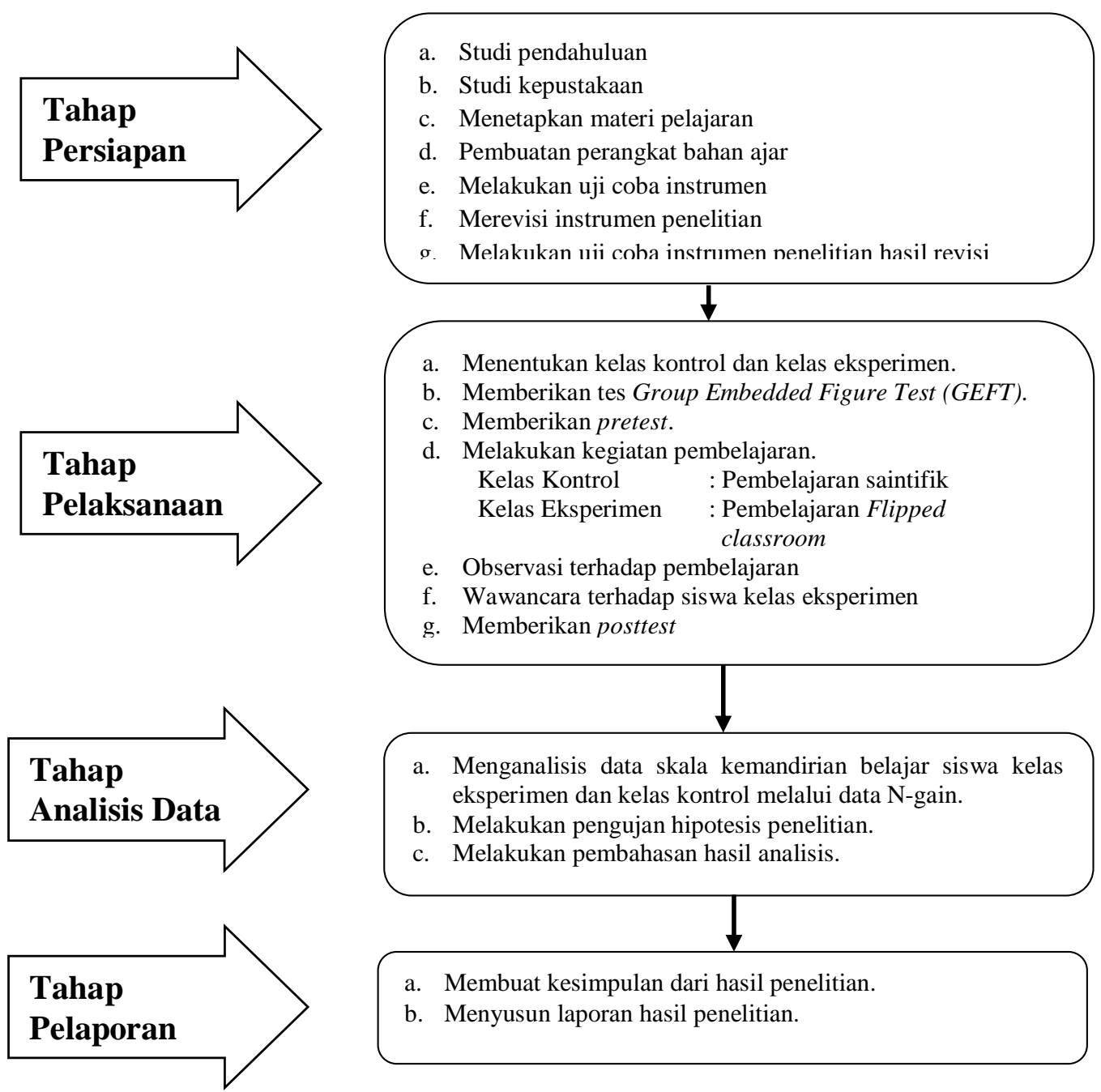

Gambar 1. Tahapan Pelaksanaan Penelitian

\section{HASIL DAN PEMBAHASAN}

Tahap pertama pelaksanaan penelitian adalah membagi kelompok siswa berdasarkan gaya kognitifnya. Untuk itu diberikan tes GEFT (Group Embed Figure Test) untuk seluruh siswa baik kelas eksperimen maupun kelas kontrol. Hasilnya diperoleh masing-masing 13 orang siswa yang memiliki gaya kognitif field independent dan field dependent untuk tiap kelas eksperimen dan kelas kontrol, sehingga jumlah total siswa yang terlibat dalam penelitian ini adalah 26 orang siswa kelas eksperimen dan 26 orang siswa kelas kontrol.

Uji statistik dilakukan untuk menunjukkan statistik deskriptif hasil sebelum dan sesudah tes pada kedua kelompok. Hasilnya dapat dilihat pada Tabel 1.

Tabel 1. Statistik Deskriptif Hasil Pretes dan Postes Kemandirian Belajar Siswa

\begin{tabular}{ccccccc}
\hline Kelas & Rata-rata & Presentase & Rata-rata & Presentase & Presentase & Standar \\
& Pretes & Pencapaian & Postes & Pencapaian & Kenaikan & Deviasi \\
& & & & Pencapaian & \\
\hline
\end{tabular}




\begin{tabular}{ccccccc}
\hline $\begin{array}{c}\text { flipped classroom } \\
\text { (FC) }\end{array}$ & 125,23 & $62,61 \%$ & 171,90 & $85,95 \%$ & $37,26 \%$ & 9,523 \\
Saintifik (ST) & 121,76 & $60,88 \%$ & 158,19 & $79,09 \%$ & $29,92 \%$ & 9,118 \\
\hline
\end{tabular}

Pencapaian skor kemandirian belajar siswa mengalami kenaikan setelah mendapat perlakuan pada kelas eksperimen sebesar 37,26\% lebih tinggi daripada kenaikan skor pada kelas kontrol sebesar 29,92\%. Ini berarti model pembelajaran flipped classroom memberikan pengaruh lebih besar terhadap pencapaian kemampuan kemandirian belajar siswa dibandingkan dengan pembelajaran saintifik. Berdasarkan gaya kognitifnya hasil pretes dan postes skala kemandirian belajar siswa pada kelas eksperimen dan kelas kontrol dapat dibandingkan seperti terlihat pada Tabel 2.

Tabel 2. Statistik Deskriptif Hasil Pretes dan Postes Kemandirian Belajar Siswa berdasarkan Gaya Kognitif Siswa

\begin{tabular}{|c|c|c|c|c|c|c|}
\hline \multirow{2}{*}{ Gaya Kognitif } & \multicolumn{2}{|c|}{$\begin{array}{c}\text { Kelas Eksperimen } \\
\text { (FC) }\end{array}$} & \multirow{2}{*}{$\begin{array}{c}\text { Presentase } \\
\text { Kenaikan } \\
\text { Skor rata-rata }\end{array}$} & \multicolumn{2}{|c|}{$\begin{array}{l}\text { Kelas Kontrol } \\
\text { (ST) }\end{array}$} & \multirow{2}{*}{$\begin{array}{c}\text { Presentase } \\
\text { Kenaikan } \\
\text { Skor rata-rata }\end{array}$} \\
\hline & $\begin{array}{c}\text { Rata-rata } \\
\text { Pretes }\end{array}$ & $\begin{array}{c}\text { Rata-rata } \\
\text { Postes }\end{array}$ & & $\begin{array}{c}\text { Rata-rata } \\
\text { Pretes }\end{array}$ & $\begin{array}{l}\text { Rata-rata } \\
\text { Postes }\end{array}$ & \\
\hline $\begin{array}{l}\text { Field Independent } \\
\text { (FI) }\end{array}$ & 121,85 & 172,00 & $41,08 \%$ & 122,23 & 156,00 & $27 \%$ \\
\hline $\begin{array}{l}\text { Field Dependent } \\
\text { (FD) }\end{array}$ & 125,23 & 172,00 & $37,00 \%$ & 121,31 & 160,00 & $32 \%$ \\
\hline
\end{tabular}

Dapat dilihat bahwa presentase kenaikan skor rata-rata skala kemandirian belajar siswa pada kelas FC untuk siswa FI lebih tinggi daripada siswa FD, sementara pada kelas kontrol presentase kenaikan skor skala kemandirian belajar siswa FI lebih rendah daripada siswa FD. Uji statistik selanjutnya diperlukan untuk mengetahui apakah terdapat perbedaan kemandirian belajar siswa antara kelas eksperimen dan kelas kontrol berdasarkan gaya kognitif FI dan FD. Hasil pretes dan postes selanjutnya digunakan untuk membuat data Ngain kemandirian belajar siswa.

Tabel 3. Statistik Deskriptif Skor N-Gain Kemandirian Belajar Siswa

\begin{tabular}{lccc}
\hline \multicolumn{1}{c}{ Kelas } & $\mathrm{n}$ & $\bar{x}$ & SD \\
\hline Eksperimen & 26 & 0,620 & 0,012 \\
Kontrol & 26 & 0,463 & 0,017 \\
\hline
\end{tabular}

Rataan gain kemandirian belajar siswa pada kelas eksperimen sebesar 0,620 lebih tinggi daripada kelas kontrol yaitu sebesar 0,463. Berikutnya hasil N-Gain dianalisis normalitas dengan menggunakan tes Saphiro-Wilk dan homogenitasnya dengan menggunakan tes Lavene. Hasilnya dapat dilihat pada Tabel 4 dan Tabel 5. 


\begin{tabular}{llccc}
\multicolumn{5}{c}{ Tabel 4. Hasil Uji Normalitas Kemandirian Belajar Siswa } \\
\hline \multicolumn{1}{c}{ Kemampuan } & \multicolumn{1}{c}{ Kelas } & Statistic & $d f$ & Sig. \\
\hline Kemandirian & Eksperimen & 0,959 & 26 & 0,368 \\
Belajar & Kontrol & 0,968 & 26 & 0,578 \\
\hline
\end{tabular}

Tabel 5. Hasil Uji Homogenitas Kemandirian Belajar Siswa

\begin{tabular}{ccccc}
\hline Kemampuan & Lavene Statistic & $d f 1$ & $d f 2$ & Sig. \\
\hline Kemandirian Belajar & 1,070 & 3 & 48 & 0,370 \\
\hline
\end{tabular}

Hasil uji normalitas menunjukkan nilai Sig. kelas eksperimen $=0,368>0,05$ dan nilai Sig. kelas kontrol 0,578 > 0,05. Ini berarti data $\mathrm{N}$-gain kemandirian belajar siswa kedua kelas normal. Sementara untuk hasil uji homogenitas diperoleh nilai Sig. $=0,058>0,05$, hal ini menunjukkan data $\mathrm{N}$-gain kemandirian belajar siswa homogen. Setelah itu dilakukan uji analisis varians dua jalan untuk mengetahui apakah peningkatan kemampuan kemandirian belajar siswa yang memperoleh pembelajaran flipped classroom lebih tinggi daripada siswa yang memperoleh pembelajaran saintifik. Hasilnya dapat dilihat pada Tabel 6.

Tabel 6. Hasil Uji Analisis Varian Dua Jalan

\begin{tabular}{lccccc}
\hline Sumber & $\mathrm{JK}$ & $\mathrm{db}$ & $\mathrm{RJK}$ & Fo & $\begin{array}{c}\text { Ftabel } \\
\alpha=0.05\end{array}$ \\
\hline Model pembelajaran & 0,32 & 1 & 0,32 & 55,08 & 4,04 \\
Gaya kognitif & 0,01 & 1 & 0,01 & 1,66 & 4,04 \\
Model pembelajaran*gaya & 0,34 & 1 & 0,34 & 58,69 & 4,04 \\
kognitif & 0,28 & 48 & 0,01 & & \\
Dalam & 0,62 & 51 & 0,01 & & \\
Total & & & & & \\
\hline
\end{tabular}

Hasil analisis varians dua jalan menunjukkan nilai Fo model pembelajaran $=55,08>$ 4,04 $=\mathrm{F}_{\text {tabel}}$, hal ini berarti terdapat perbedaan peningkatan kemandirian belajar siswa antara kelas flipped classroom dan kelas saintifik. Sementara nilai Fo gaya kognitif $=1,66<4,04$ $=F_{\text {tabel }}$ menunjukkan bahwa tidak terdapat perbedaan peningkatan kemandirian belajar antara siswa dengan gaya kognitif field independent dan field dependent pada pembelajaran flipped classroom. Namun terdapat interaksi antara model pembelajaran dan gaya kognitif siswa, hal ini ditunjukkan dengan nilai Fo interaksi antara model pembelajaran dan gaya kognitif $=58,69>4,04=\mathrm{F}_{\text {tabel }}$.

Berdasarkan hasil uji lanjutan simple effect untuk menguji perbedaan antara kelas flipped classroom dan kelas saintifik untuk gaya kognitif field independent diperoleh nilai $\mathrm{t}_{\mathrm{o}}=4,26>1,68=\mathrm{t}_{\mathrm{tab}}$. Hal tersebut menunjukkan bahwa peningkatan kemandirian belajar siswa dengan faya kognitif field independent pada kelas flipped classroom lebih tinggi 
daripada kelas saintifik. Begitupun dengan hasil uji lanjutan simple effect untuk menguji perbedaan antara kelas flipped classroom dan kelas saintifik untuk gaya kognitif field dependent diperoleh nilai $\mathrm{t}_{\mathrm{o}}=6,24>1,68=\mathrm{t}_{\text {tab }}$. Ini berarti peningkatan kemandirian belajar siswa dengan gaya kognitif field dependent pada kelas flipped classroom lebih tinggi daripada kelas saintifik.

Peningkatan pencapaian skala kemandirian belajar siswa yang ditunjukkan pada tabel 1 dan tabel 2 untuk kelas flipped classroom secara umum lebih tinggi daripada kelas saintifik. Hal ini dapat terjadi karena dalam pembelajaran flipped classroom, siswa dituntut untuk mengelola waktu belajar baik di rumah maupun di sekolah, membuat target penyelesaian tugas dan menyusun banyak pertanyaan untuk didiskusikan di kelas tatap muka. Hal ini sesuai dengan prinsip pembelajaran flipped classroom yaitu guru meminimalkan pemberian instruksi langsung dan lebih mengefektifkan interaksi satu-satu dengan siswa (Bishop dan Verleger, 2013). Sementara siswa akan lebih banyak berdiskusi dengan berbekal pemahaman materi pelajaran yang mereka pelajari sebelumnya di rumah melalui handout atau video pembelajaran yang diberikan guru.

Uji analisis varians dua jalan untuk model pembelajaran menghasilkan nilai $\mathrm{Fo}=$ 55,08 > 4,04 $=\mathrm{F}_{\text {tabel}}$, ini menunjukkan bahwa siswa kelas eksperimen mengalami peningkatan dalam kemampuan kemandirian belajar lebih baik dibandingkan siswa pada kelas kontrol. Sesuai dengan tiga prinsip yang diterapkan pada pelaksanaan pembelajaran flipped classroom menurut Strayer, Hart dan Bleiler-Baxter (2016) adalah: 1) gunakan luarkelas untuk mendorong siswa merefleksi dan memperoleh tanggapan dari teman-temannya, 2) gunakan tugas dalam-kelas untuk membangun pengetahuan baru sebagai bagian dari komunitas belajar di kelas, dan 3) hubungkan tugas luar-kelas dan dalam-kelas dengan pendekatan instruksi yang serupa. Untuk pengelolaan kegiatan pembelajaran di kelas lebih rinci diuraikan oleh Baker (2016) menjadi empat tahap kegiatan belajar, yaitu 1) Klarifikasi: memulai diskusi dengan mengajukan pertanyaan untuk siswa yang telah ditugaskan untuk mempelajari materi sebelumnya, 2) Ekspansi: selanjutnya siswa diajak untuk menyusun bahan pelajaran berdasarkan hasil pengalamannya sendiri atau bahan bacaan yang lain. Tahap ini menjadikan siswa berperan sebagai kontributor pengetahuan dan mampu menempatkan materi tersebut ke dalam pengalaman pribadinya, 3) Aplikasi: kontribusi penting dari sebuah model pembelajaran adalah waktu yang disediakan untuk siswa dapat memahami dan menerapkan konsep. Model flipped classroom menyediakan banyak waktu untuk siswa dalam memahami dan menerapkan konsep tanpa mengorbankan waktu untuk 
mempelajari materi, dan 4) Latihan: tahap ini melibatkan kelompok siswa untuk berkolaborasi dan berpikir kritis dan kreatif.

Hasil uji lanjut terhadap perbedaan rata-rata tiap gaya kognitif pada kelas eksperimen dan kelas kontrol menunjukkan bahwa peningkatan kemampuan kemandirian belajar siswa FI pada kelas eksperimen lebih tinggi daripada siswa FI kelas kontrol. Begitupun dengan peningkatan kemampuan kemandirian belajar siswa FD pada kelas eksperimen yang lebih tinggi daripada siswa FD kelas kontrol. Secara umum pembelajaran flipped classroom menyediakan ruang yang cukup bagi siswa untuk menggali pengetahuannya secara mandiri dan menggunakan cara yang lebih sesuai dengan karakteristik siswa dalam belajar. Kesempatan siswa untuk berkolaborasi, beradu argumen dalam diskusi diberikan pada saat pertemuan tatap muka secara penuh, tanpa terpotong waktu untuk mempelajari materi di dalam kelas. Inilah keunggulan model pembelajaran flipped classroom yang menyediakan waktu yang seluas-luasnya untuk siswa dapat memahami dan menerapkan konsep melalui interaksi personal dan sosial.

Uji analisis varians dua jalan terhadap gaya kognitif tidak menunjukkan perbedaan peningkatan kemandirian belajar antara siswa FI dan siswa FD dalam pembelajaran flipped classroom, hal ini menegaskan bahwa pembelajaran flipped classroom dapat meningkatkan kemampuan kemandirian belajar siswa secara bersama-sama baik siswa dengan gaya kognitif FI maupun siswa dengan gaya kognitif FD. Sesuai dengan pendapat Albanese dan Bush (2015) yang mengunggulkan model pembelajaran flipped classroom sebagai pembelajaran yang memberikan kebebasan siswa untuk belajar sesuai dengan kecepatan mereka sendiri, memungkinkan penemuan beberapa strategi solusi serta yang paling penting adalah siswa dapat mengambil hak milik atas pembelajaran mereka sendiri, dengan kata lain mereka belajar secara mandiri.

\section{KESIMPULAN}

Dari hasil penelitian ini secara umum dapat disimpulkan bahwa model pembelajaran flipped classroom memberikan pengaruh yang signifikan pada peningkatan kemampuan kemandirian belajar siswa dibandingkan dengan siswa yang memperoleh pembelajaran saintifik. Hasil analisis statistik deskriptif menunjukkan bahwa terdapat kenaikan rata-rata kemandirian belajar siswa pada kelas flipped classroom sebesar 37\% lebih tinggi daripada kenaikan rata-rata kemandirian belajar siswa pada kelas saintifik sebesar 29\%. Hasil uji statistik analisis varians dua jalan menunjukkan bahwa : 1) terdapat perbedaan peningkatan kemampuan kemandirian siswa pada kelas flipped classroom dan kelas saintifik. 
Peningkatan kemampuan kemandirian belajar siswa kelas flipped classroom lebih tinggi daripada kelas saintifik, dan 2) terdapat perbedaan peningkatan kemampuan kemandirian siswa pada kelas flipped classroom dan kelas saintifik berdasarkan gaya kognitif field independent dan field dependent. Dengan uji lanjut scheffe'dapat disimpulkan bahwa peningkatan kemampuan kemandirian belajar siswa field independent pada kelas flipped classroom lebih tinggi daripada siswa field independent pada kelas saintifik. Begitu juga dengan peningkatan kemampuan kemandirian belajar siswa field dependent pada kelas flipped classroom lebih tinggi daripada siswa field dependent pada kelas saintifik.

Penelitian ini dapat dilanjutkan untuk sampel yang lebih besar, variatif serta waktu penelitian yang lebih lama karena untuk penelitian yang menguji softskill akan lebih baik dilakukan pada rentang waktu yang lama dan jenis sampel yang beragam. Perhatian guru untuk menerapkan model pembelajaran yang tepat dapat memberikan siswa kesempatan untuk mengembangkan kemampuan kemandirian belajarnya. Pengetahuan guru dalam memahami karakteristik siswa berdasarkan gaya kognitif juga dapat membantu siswa mendapatkan pengalaman belajar yang bermakna.

\section{REFERENSI}

Albanese, J., \& Bush, S. B. (2015). The Flipped Classroom: An Avenue for StudentCentered Learning. Retrieved February 25, 2019, from https://www.nctm.org/Publications/Mathematics-Teaching-in-MiddleSchool/Blog/The-Flipped-Classroom_-An-Avenue-for-Student-Centered-Learning/

Baker, J. W. (2016). The Origins Of "The Classroom Flip." In J. Overmyer \& N. Yestness (Eds.), Proceedings of the 1 St Annual Higher Education Flipped Learning Conference (p. 15). Greeley, Colorado: University of Northern Colorado. Retrieved from https://digscholarship.unco.edu/cgi/viewcontent.cgi?article=1058\&context=heflc\#pag $\mathrm{e}=21$

Bishop, J., \& Verleger, M. (2013). The Flipped Classroom : A Survey of the Research. Proceedings - Frontiers in Education Conference, FIE, 161-163. https://doi.org/10.1109/FIE.2013.6684807

Khoiriyah, N. (2013). Analisis Tingkat Berpikir Siswa Berdasarkan Teori Van Hiele Pada Materi Dimensi Tiga Ditinjau dari Gaya Kognitif Field Dependent dan Field Independent. Universitas Sebelas Maret Surakarta.

Lee, M.-K. (2018). Flipped classroom as an alternative future class model?: implications of South Korea's social experiment. Educational Technology Research and Development, $1,1-21$.

Li, F., Xie, R., Li, X., \& Li, W. (2015). The influence of perceptual information on control processes involved in self-regulated learning : evidence from item selection. Psychon Bull Rev, 22, 1007-1013. https://doi.org/10.3758/s13423-014-0762-7

Lo, C. K., \& Hew, K. F. (2017). A critical review of flipped classroom challenges in K-12 education: possible solutions and recommendations for future research. Research and Practice in Technology Enhanced Learning, 12(1), 4. https://doi.org/10.1186/s41039016-0044-2 
Loyens, S. M. M., Magda, J., \& Rikers, R. M. J. P. (2008). Self-directed learning in problembased learning and its relationships with self-regulated learning. Educational Psychology Review, 20(4), 411-427. https://doi.org/10.1007/s10648-008-9082-7

Nindiasari, H. (2013). Meningkatkan Kemampuan dan Disposisi Berpikir Reflektif Matematis Serta Kemandirian Belajar Siswa SMA Melalui Pembelajaran Dengan Pendekatan Metakognitif. Universitas Pendidikan Indonesia.

Onyekuru, B. U. (2015). Field Dependence-Field Independence Cognitive Style, Gender, Career Choice and Academic Achievement of Secondary School Students in Emohua Local Government Area of Rivers State. Journal of Education and Practice, 6(10), 7686.

Strayer, J. F., Hart, J. B., \& Bleiler-Baxter, S. K. (2016). Flipped Classroom. The Mathematics Teacher, 109(9), 662-668. https://doi.org/10.5152/tcb.2015.064

Sugiyono. (2009). Metode Penelitian Pendidikan (7th ed.). Bandung: CV ALFABETA.

Tucker, B. (2013). The Flipped Classroom. Education Next, 105 No. 2.

Witkin, H. A., Moore, C. A., Goodenough, D., \& Cox, P. W. (1977). Field-Dependent and Field-Independent Cognitive Styles and Their Educational Implications. Review of Educational Research, 47(1), 1-64. https://doi.org/10.3102/00346543047001001

Yamada, M., Shimada, A., Okubo, F., Oi, M., Kojima, K., \& Ogata, H. (2017). Learning analytics of the relationships among self-regulated learning, learning behaviors, and learning performance. Research and Practice in Technology Enhanced Learning, 12(1), 13. https://doi.org/10.1186/s41039-017-0053-9

Zheng, L. (2016). The effectiveness of self-regulated learning scaffolds on academic performance in computer-based learning environments: a meta-analysis. Asia Pacific Education Review, 17(2), 187-202. https://doi.org/10.1007/s12564-016-9426-9 